The International Journal of Engineering and Science (IJES)

|| Volume || 6 || Issue || 12 || Pages || PP 01-10 || 2017 ||

ISSN (e): $2319-1813$ ISSN (p): $2319-1805$

\title{
Growth of oil/gas and non oil/gas trade sectors: The impact on labor-force participation rates in Indonesia
}

\author{
Andi Sessu \\ Faculty of Economics and Business \\ UHAMKA Jakarta, Indonesia
}

\begin{abstract}
-
Export trade balance, oil and non-oil imports, Indonesia is in an active state or economy to prosper, while the results of multiple regression analysis showed that the export of non oil/gas, non oil/gas import, oil and gas imports and economic growth positive effect on the labor force participation rate, which means every increased four variables also increased labor force participation rate, while oil and gas exports have negative effect means that any increased export of oil and gas resulting in a decline in labor force participation rates and significant effect of all the variables of the labor force participation rate in Indonesia. Multiple correlation coefficients obtained $r=0.998$ shows the effect of variable export of non oil/gas, non oil/gas import, export of oil and gas, oil and gas imports, economic growth together very strong and the coefficient of determination together the five variables can be $R=0.996$ shows the percentage contribution of influence together of $99 \%$ means that only $0.01 \%$ contribution of other variables influence the level of labor force participation in Indonesia. It can be concluded that the development of oil and gas trade and non-oil and gas in Indonesia still need cooperation between individual communities, private sector, civil society and government in an effort to increase trade in Indonesia, because it is very big influence on the labor force participation rate that could lower the unemployment rate and can automatically reducing poverty, because unemployment and poverty in Indonesia is still high when compared with some other countries in the world.
\end{abstract}

Keywords - trading export, import of oil/gas sectors and non oil/gas economic growth, labor-force participation

Date of Submission: Date 28-11-2017

Date of Acceptance : Date 05-12-2017

\section{INTRODUCTION}

Indonesia's economic growth of the last few years is quite encouraging compared to some other countries in the world, however, economic growth has not been able to solve the problems the economy faced by Indonesian nation is the problem of unemployment and poverty (Siregar and Wahyuniarti, 2007). Economy of a country is said to be advanced one indicator that is considered is the problem of unemployment and poverty mean that Indonesia is still considered underdeveloped economies, they need no effort or hard work began of individual communities, private sector and government in an effort to boost economic development in Indonesia (Aroef et al. 2009 ). Indonesia's economic growth as the data in the following the table:

Table 1. Indonesian Economic growth

\begin{tabular}{|l|c|}
\hline Years & Economic growth ( \% ) \\
\hline 2010 & 6,1 \\
\hline 2011 & 6,5 \\
\hline 2012 & 6,3 \\
\hline 2013 & 5,8 \\
\hline 2014 & 5,1 \\
\hline 2015 & 5,7 \\
\hline 2016 & 5,3 \\
\hline
\end{tabular}


Table 1 shows that the Indonesian economic growth from 2010 to 2016 is still considered decreased, while economic growth is absolutely necessary in the efforts of labor, labor force absorption be required an effort to reduce unemployment, poverty and income inequality public.

Table 2. Development of work force, work population, unemployment, LFPR and TPT

\begin{tabular}{|c|c|c|c|c|c|}
\hline Years & $\begin{array}{c}\text { Labor force } \\
\text { (Million } \\
\text { people) }\end{array}$ & $\begin{array}{c}\text { Labour } \\
\text { (Million } \\
\text { people) }\end{array}$ & $\begin{array}{c}\text { Unemployment } \\
\text { (Million people) }\end{array}$ & $\begin{array}{c}\text { Labor Force } \\
\text { Participation Rate } \\
\text { (LFPR/TPAK) }(\%)\end{array}$ & $\begin{array}{c}\text { Open Unemployment } \\
\text { Rate (OUR/TPT) (\%) }\end{array}$ \\
\hline$(1)$ & $(2)$ & $(3)$ & $(4)$ & $(5)$ & $(6)$ \\
\hline 2001 & 98,81 & 90,81 & 8,01 & 68,6 & 8,1 \\
\hline 2002 & 100,78 & 91,65 & 9,13 & 67,76 & 9,06 \\
\hline 2003 & 102,75 & 92,81 & 9,94 & 67,86 & 9,67 \\
\hline 2004 & 103,97 & 93,72 & 10,25 & 67,54 & 9,86 \\
\hline 2005 & 105,86 & 93,96 & 11,9 & 66,79 & 11,24 \\
\hline 2006 & 106,39 & 95,46 & 10,93 & 66,16 & 9,28 \\
\hline 2007 & 109,94 & 99,93 & 10,01 & 66,99 & 8,39 \\
\hline 2008 & 111,95 & 102,55 & 9,39 & 67,18 & 7,87 \\
\hline 2009 & 113,83 & 104,87 & 8,96 & 67,23 & 7,14 \\
\hline 2010 & 116,53 & 108,21 & 8,32 & 67,72 & 6,56 \\
\hline 2011 & 117,37 & 109,67 & 7,7 & 68,34 & \\
\hline
\end{tabular}

The data in table 2 of the development of the labor force from the 2001 to 2011 has increased, labor force that works from $1997-2011$ have also increased, unemployment of $1997-1999$ increased and in 2000 dropped from the year 2000 to 2006 increased, whereas in the year 2006 to 2011 decreased, but unemployment in Indonesia is still very high, can be described as follows.

Figure 1. Labor Force Participation Rate

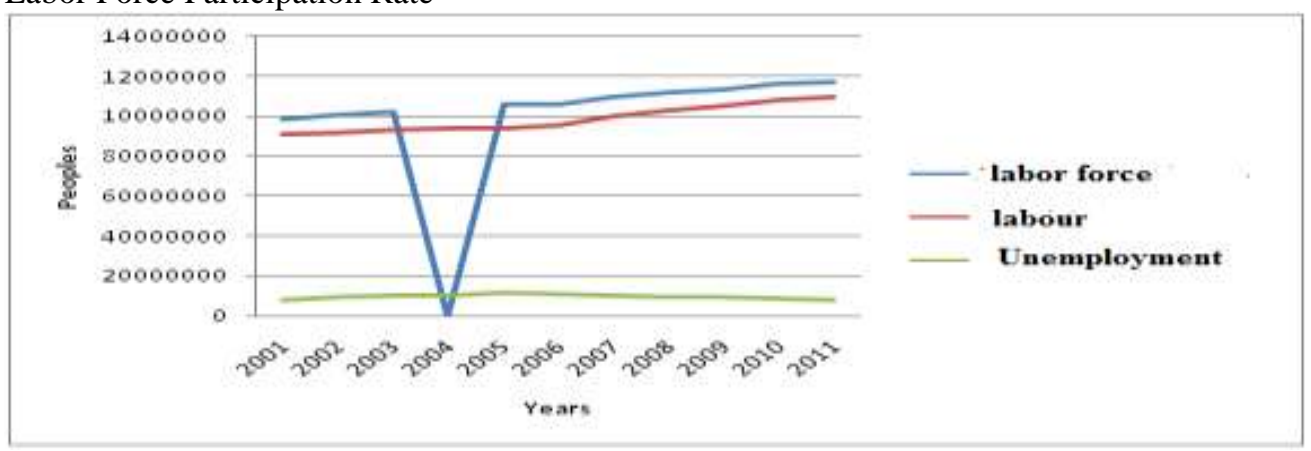

Figure 2. Labor Force, Employed Population and open unemployment rate

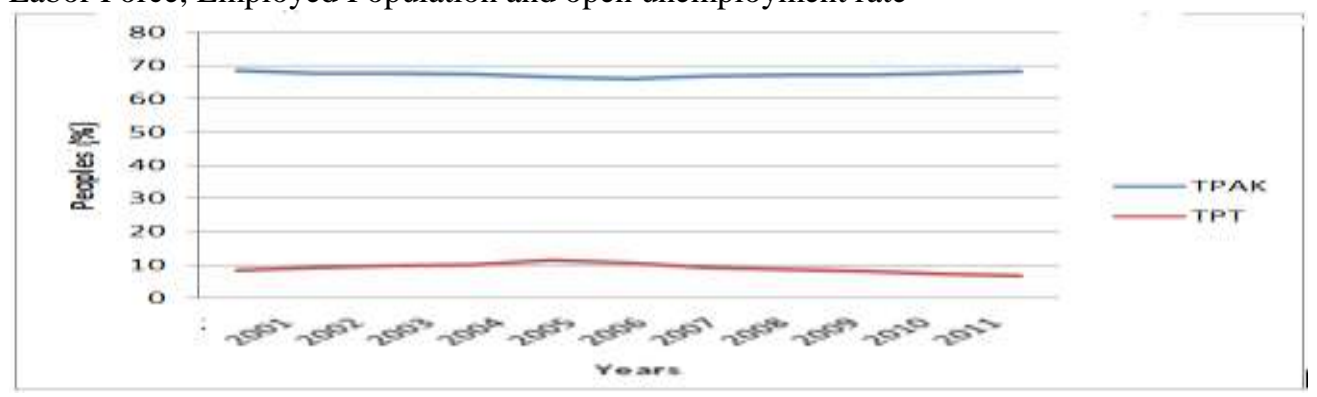

Indonesia is one of the rich countries in the world, rich in natural resources and human resources only the quality of human resources still need to be taken seriously no maximum efforts of individual communities, civil society organizations and the government to improve its quality is the quality of the knowledge, skill, 
creative, innovative, independence and quality of various other characters as well as the ability of repair or damage control natural resources is increasing is now experienced by the people of Indonesia are very concerned (Tan et al., 2017) economic development is very big influence on addressing the problems experienced by the Indonesian people are unemployed, employment, poverty, improve social welfare. Populist economic development required human resource development policies, because the quality of human resources is seen as one of the key factors in the era of populist economic growth, national trade and free trade. Mastery of science and technology in addition to these factors, entrepreneurship is seen as a key factor in the era of free trade, essentially stems from the quality of human resources or a reliable worker.

The role of worker resources here are not solely limited to workers in the bottom layer, but includes all layers, from the workers (blue collar workers) up to the management level (white-collar worke) (Hidayat, 2016). The strategy should be developed for economic empowerment of the people is put potential that has not been exploited or explored more seriously in a broader economic perspective (extend). Potentials for empowerment such as the agribusiness, marine, agriculture and plantations, agro-industry. In this context, building a democratic economy that can compete in the global economy level aimed at exploiting the potential of the nation (Roesmanto, 2007). In terms of strategy, there are some things that need to be considered and developed in the direction of economic development, namely the equal opportunity to have the assets of the national economy, the government's attention to the small and medium enterprises, protection of the people's economy, cultivate the informal economy and organize a cooperative in accordance with the spirit and the demands of globalization. Results of previous studies show the important role of exports in economic growth and job creation (Tambunan, 2001; Saimul, 2017; Alisjahbana \& Busch, 2017).

\section{LITERATURE REVIEW}

\subsection{Economic growth}

Economic growth is something that in desire every country in the world, but not as easy as it can be achieved because there are many factors that affect economic growth is a process of changes in economic conditions of a country continuously towards a better state for a certain period. Economic growth can be defined as well as the increase in production capacity of an economy that is realized in the form of increase in national income. Their economic growth is an indication of the success of economic development. Measuring the economic growth of a country can be measured by comparing, for example, for a national measure, Gross National Product (GNP), the current year to the previous year (Tambunan, 2001).

\subsection{Labor Force Participation Rate}

The labor force is the number of population of productive age level, for the Indonesian population of productive age population that is in the interval of 15 years of age until the age of 65 years. Labor force participation rates for men at a certain age is the proportion of men included in that age shall be classified as members of the workforce (Pollard et al., 1990). The labor force participation rate is the ratio between the labor forces by mid-year population (Bakir and Manning, 1984). This is formulated as follows:

\begin{tabular}{|c|c|}
\hline \multirow{3}{*}{ Employment Opportunities = } & People in work \\
\hline & \\
\hline & number of labor force \\
\hline \multirow{2}{*}{ Labor Force Participation Rate $=$} & People in work \\
\hline & the working age population \\
\hline \multirow[b]{2}{*}{ Unemployment $=$} & Number of unemployment \\
\hline & \\
\hline
\end{tabular}

\subsection{Oil/gas and non oil/gas}

Gas is a commodity which is a derivative of petroleum products and gas, while the non-oil is the stuff out of gas and earth or goods that are not in the form of oil and gas such as agriculture, plantation, fishery, animal husbandry and so on etc (Sugiyono, 2017). 


\subsection{Export and import}

Export is the expenditure of goods and services from domestic to foreign countries, while imports include the import of goods and services from abroad into the country. Export is closely related to GDP, which are the increased exports will increase in the GDP also ceteris paribus condition. The main import determinant is income of the people of a State. If the State's revenue change, then naturally imports will also change, namely the higher the income, the higher country imports and vice versa.

Exports and imports are closely related to the balance of trade (Trade Balance), export is a component of the national income, changes in the value of exports will affect the level of national income, if exports greater than imports of the national income will increase so that the balance of payments surplus (Inflation) (Tambunan and Wijanarko, 2000). If the import of goods greater than the national export revenue will be decreased so that the balance of payments deficit (Deflation) (Hasmarini and Murtiningsih, 2017).

\subsection{Effect of changes in exports on the trade balance}

Important factor in the direction of flow export and import is an improvement in the trade balance, which has experienced a huge increase. The trade surplus large is able to cover the deficit in the balance of trade in services and the deficit in capital flows. Although the effect of the increase of exports to imports of the same magnitude to the effect of an increase in investment to imports, however in terms of the balance of payments effects of changes in export is not equal to the change in investment (Widyasanti, 2010). A clear increase in imports as a result of the increased investment is not preceded by ekspor.Ini rise means that the increase in exports is always the tendency to increasing or decreasing surplus balance of payments deficit. Instead declining export value always resulted in increased or decreased deficit balance of payments surplus. Improved trade balance requires rapid export growth. In addition to the entrepreneurs need in that direction, encouragement is needed. Creating it is our collective responsibility, government, government administration, employers and society in general (Husman 2007).

The negative impact that may occur as a result of international trade occurs when can be affect on national economy by the circumstances of the world market. If the Indonesian government had not responded to the world market situation, then Indonesia will be left behind by other countries. Such conditions affect changes to the national development policies that have been established if global conditions have a negative impact on people's lives (Tambunan, 2001).

\section{METHODS}

The data that will be used is the economic growth, export, import of oil/gas and non oil/gas, the level of employment, labor force participation rate, poverty rate, unemployment rate Indonesia all this data in Jakarta, this research is conducted in Jakarta Central Statistics Agency office and related agencies' offices. For research purposes only propose that with increasing economic growth, export, import of oil and non-oil, the rate of employment and labor force participation rates can reduce the level of poverty in Indonesia, it is considered that the population data of all data in Indonesia related to these variables. By him that investigators determined the study population all national-level data related to the research problem in BPS-Statistics Indonesia and on the relevant agencies.

Because of the ability of researchers in terms of time and energy is limited, so in this study is limited in that the data sample last 15 years, i.e. from the data from 2001 to 2015 , the data concerning the increase in economic growth, employment and labor force participation rates and poverty rates in Indonesia. Draft analysis to be used in between descriptive statistics to be able to provide an overview on research and Inferential statistics for testing the hypothesis that the frequency distribution table groups, chart histograms and polygons frequency, mean, variance, median, mode, standard deviation, formula workforce, formula employment, formula unemployment rate, labor force participation rate formula, formulas level of poverty, multiple linear regression (Ghozali, 2005).

Multiple regression models:

$$
Y=a_{0}+a_{1} x_{1}+a_{2} x_{2}+a_{3} x_{3}+a_{4} x_{4}+a_{5} x_{5}+e,
$$

\section{Where:}

$$
\begin{aligned}
\mathrm{Y} & =\text { labor force participation rate } \\
\mathrm{a} & =\text { constant } \\
\mathrm{b}, \mathrm{c}, \mathrm{d} & =\text { regression coefficient }
\end{aligned}
$$




$\begin{array}{lll}X_{1} & = & \text { Economic growth } \\ X_{2} & = & \text { level of oil and gas exports } \\ X_{3} & = & \text { level of oil and gas imports } \\ X_{4} & = & \text { level of non oil/gas exports } \\ X_{5} & = & \text { level of non oil/gas import }\end{array}$

\section{RESUlts}

The data of oil/gas exports and non oil/gas, economic growth, labor force participation rate from 2001 to 2015 obtained in the following table:

Table 3. Export trading, oil/gas and non oil/gas imports, economic growth, the labor force participation rate

\begin{tabular}{|c|c|c|c|c|c|c|}
\hline Years & $\begin{array}{l}\text { non oil/gas } \\
\text { exports }\left(X_{1}\right)\end{array}$ & $\begin{array}{l}\text { non oil/gas } \\
\text { import }\left(\mathrm{X}_{2}\right)\end{array}$ & $\begin{array}{l}\text { oil and gas } \\
\text { exports }\left(\mathrm{X}_{3}\right)\end{array}$ & $\begin{array}{l}\text { oil and gas } \\
\text { imports }\left(\mathrm{X}_{4}\right)\end{array}$ & $\begin{array}{c}\text { economic } \\
\text { growth }(\%)\left(\mathrm{X}_{5}\right)\end{array}$ & $\begin{array}{c}\text { Labor Force } \\
\text { Participation Rate } \\
(\text { LFPR/TPAK) (Y) }\end{array}$ \\
\hline 2001 & 43684,6 & 25490,3 & 12636,3 & 5471,8 & 3,5 & 90,81 \\
\hline 2002 & 45046,1 & 24763,1 & 12112,7 & 6525,8 & 3,7 & 91,65 \\
\hline 2003 & 47406,8 & 24939,8 & 13651,4 & 7610,9 & 4,1 & 92,81 \\
\hline 2004 & $\begin{array}{l}55939,3 \\
5\end{array}$ & 34792,5 & 15645,3 & 11732,0 & 4,8 & 93,72 \\
\hline 2005 & 66428,4 & 40243,2 & 19231,6 & 17457,7 & 5,6 & 93,96 \\
\hline 2006 & 79578,7 & 42102,6 & 21219,9 & 18962,9 & 5,5 & 95,46 \\
\hline 2007 & 92012,3 & 52540,6 & 22088,6 & 21932,8 & 6,3 & 99,93 \\
\hline 2008 & 107894,1 & 98644,4 & 29126,3 & 30552,9 & 6,1 & 102,55 \\
\hline 2009 & 97491,7 & 77848,5 & 19018,3 & 18980,7 & 4,5 & 104,87 \\
\hline 2010 & 129739,5 & 108250,6 & 28039,6 & 27412,7 & 6,1 & 108,21 \\
\hline 2011 & 162019,6 & 136734,1 & 41477,0 & 40701,5 & 6,5 & 109,67 \\
\hline 2012 & 153043,0 & 149125,3 & 36977,3 & 42564,2 & 6,3 & 112,5 \\
\hline 2013 & 149918,8 & 141362,3 & 32633,0 & 45266,4 & 5,8 & 112,76 \\
\hline 2014 & 145961,2 & 134718,9 & 30018,8 & 43459,9 & 5,1 & 114,63 \\
\hline 2015 & 131791,9 & 118081,6 & 18574,4 & 24613,2 & 5,7 & 118,2 \\
\hline
\end{tabular}

Figure 3. Export, oil/gas and non oil/gas imports

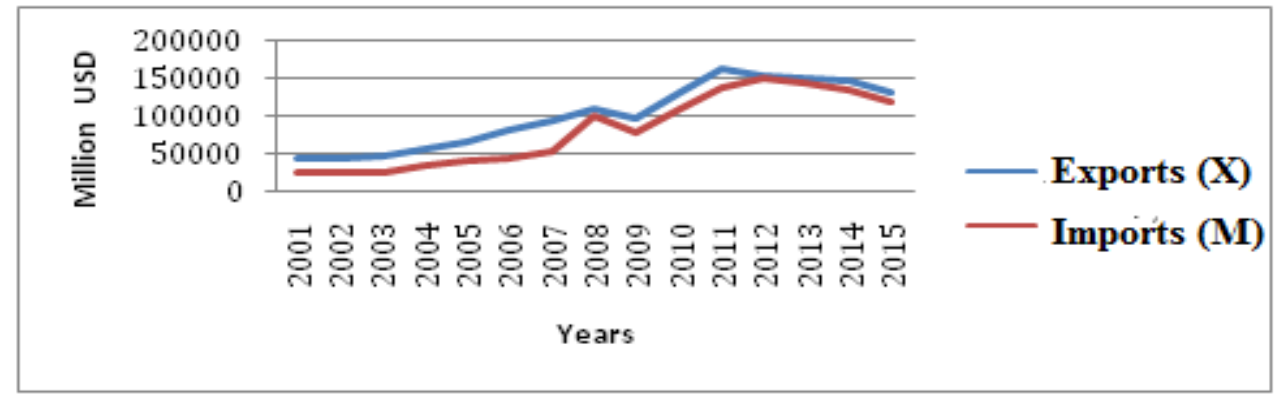

Based on the charts from 2001 to 2015 exports is always greater than imports, the trade balance showed exports, oil and gas imports and Indonesia's non-oil is in an active state or a profitable economy. 
Figure 4. Export and import of oil and gas

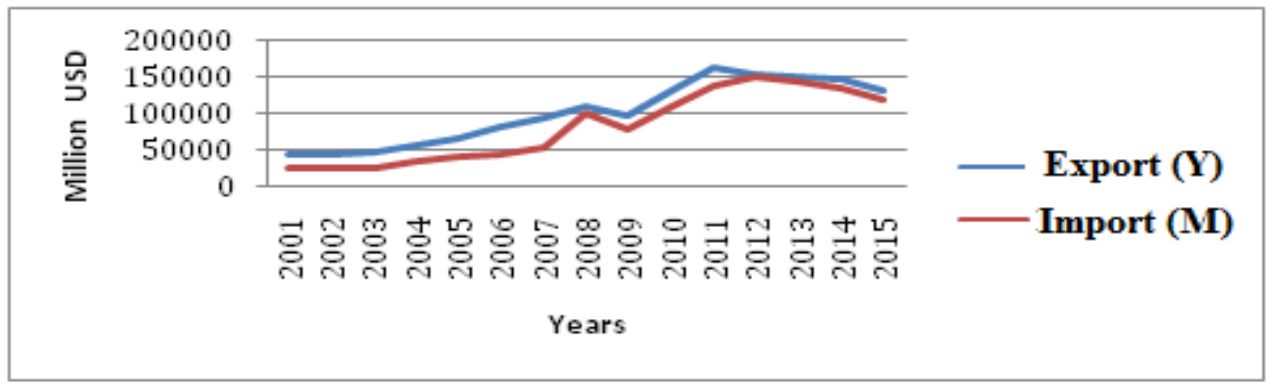

On the charts from 2001 to 2015 show that exports are always greater than imports, the trade balance showed exports, specifically oil and gas imports, Indonesia is in an active state or a profitable economy

Figure 5. Exports and imports of oil and gas

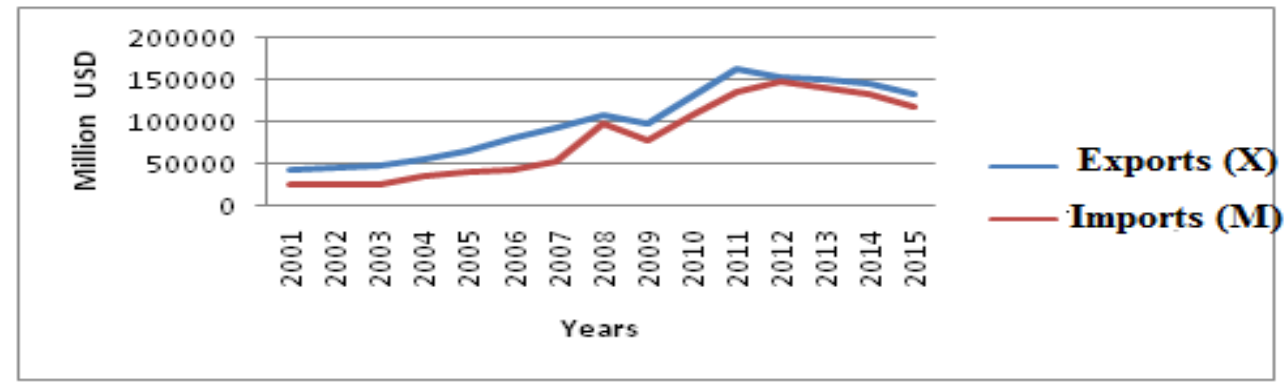

Based on the charts from 2001 to 2015 exports is always greater than imports, the trade balance showed exports, non oil/gas imports, Indonesia is in an active state or a profitable economy. From the results of multiple regressions analysis was obtained:

$Y=86,823,908.89+229.669 x^{1}+101.414_{x}{ }^{2}-796.0753 x^{3}+28.331_{x}{ }^{4}+510,724.21 x^{5}$

These results indicate that the export of non oil/gas, non oil/gas import, oil and gas imports and economic growth has a positive effect, which means every increased four variables also increased labor force participation rate, while oil and gas exports have negative effect means that any increase oil exports resulted in a decline in labor force participation rates and all variables have a significant effect on the labor force participation rate in Indonesia, because the influence of independent variables on the dependent variable significant together with the values of F-statistics at 434.574. The results of the analysis of multiple correlation coefficients obtained the value of $r=0.998$ shows the effect of variable export of non-oil, non-oil import, export of oil and gas, oil and gas imports, economic growth together very strong and the coefficient of determination together the five variables can be make a contribution $\mathrm{R}=0.996$ indicates the percentage jointly influence of $99 \%$ means that only $0.01 \%$ contribution of other variables influence the level of labor force participation in Indonesia.

Figure 6.Histogram

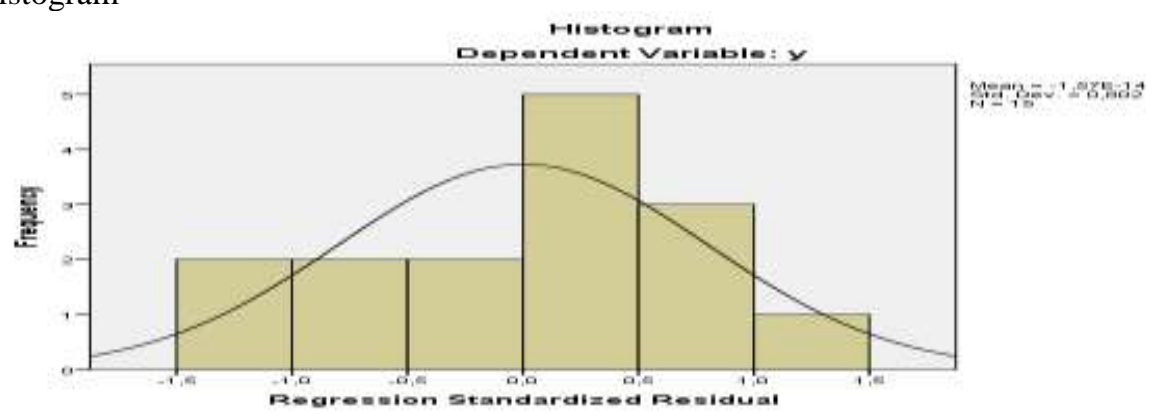


Figure 7. Normalized

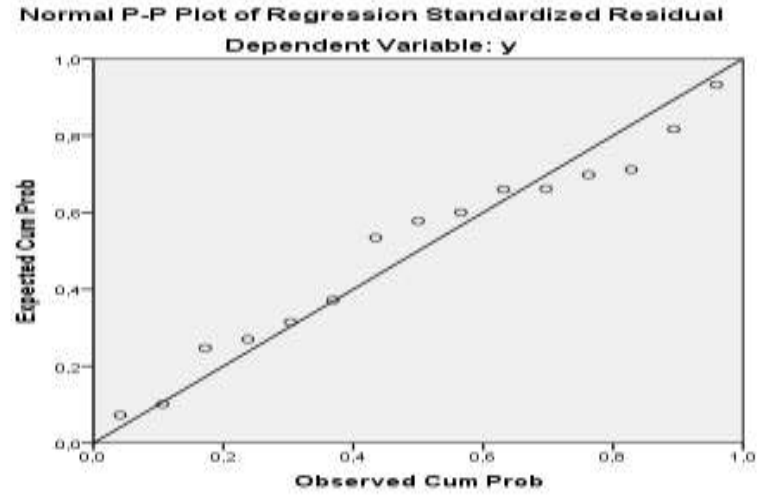

\section{CONCLUSION}

The results of multiple regression analysis showed that the export of non oil/gas sectors, non oil/gas imports, oil imports and economic growth positive effect on labor force participation rate, which means every increased four variables also increased labor force participation rate, while oil and gas exports increased negative effect means any oil and gas exports resulted in a decline in labor force participation rates and significant effect of all the variables of the labor force participation rate in Indonesia.

The results of the analysis of multiple correlation coefficients obtained $r=0.998$ shows the effect of variable export of non-oil, non-oil import, export of oil and gas, oil and gas imports, economic growth together very strong and the coefficient of determination together the five variables can be $\mathrm{R}=0.996$ indicates the percentage contribution jointly influence of $99 \%$ means that only $0.01 \%$ contribution of other variables influence the level of labor force participation in Indonesia. It can be concluded that the development of oil and gas trade and non-oil and gas in Indonesia still need cooperation between individual communities, private sector, civil society and government in an effort to increase trade in Indonesia, because it is very big influence on the labor force participation rate that could lower the unemployment rate and can automatically reducing poverty, because unemployment and poverty in Indonesia is still high when compared with some other countries in the world.

The Indonesian government is recommended in order to increase development aid policy means supporting the activities of agriculture and plantations, such as the agriculture industry and plantations in Indonesia is still around 50\% expect rainfed, so there needs to be an idea or effort so that rainwater given by God Almighty does not squandered that with the construction of dams and irrigation that can collect rain water, increase the knowledge, skills Indonesian people through formal or non-formal can form qualified human resources who can manage raw material gas into finished goods new oil and gas in exports, so that it can increase the labor force participation rate, could have an impact on the level of unemployment and poverty reduction in Indonesia, suppressed import policy export policy be improved by supporting the activities of agriculture, plantation, farming, fishing and domestic industries as well as industrial conglomerate.

\section{REFERENCES}

[1] Alisjahbana, A. S., \& Busch, JM (2017). Forestry, Forest Fires, and Climate Change in Indonesia. Bulletin of Indonesian Economic Studies, 53 (2), 111-136.

[2] Aroef, M., Djamal, J. S., \& Ilwan, H. (2009). Grand techno-economic strategy: a strategy to win the competition sparked global productivity. PT Mizan Publika.

[3] Bakir, S. Z., \& Manning, C. (1984). The labor force in Indonesia: participation, opportunities and unemployment. Published for the Population Research Center UGM [by] the Eagles.

[4] Ghozali, Imam. (2005). Applications Multivariate Analysis with SPSS Program. Publisher Agency Diponegoro University. Semarang

[5] Hasmarini, M. I., \& Murtiningsih, D. (2017). Causality Analysis of Non-Oil Exports by Economic Growth Method Using Final Prediction Error. Journal of Economic Development: Economic Issues and Development Studies, 4 (2), 147-161.

[6] Hidayat, H. (2016). Strategic role of intellectual capital in business competition in an era of services. Equity (Journal of Economics and Finance), 5 (3), 293-312. 
[7] Husman, JA (2007). Effect of Exchange Rate Against Real Indonesian Bilateral Trade Balance: The Marshall-Lernerdan J-curve phenomenon. Bulletin of Monetary Economics and Banking (Bulletin of Monetary Economics and Banking), 8 (3), 1-26.

[8] Pollard, A.H., F. Yusuf, \& G.N. Pollard. (1990). Demographic Techniques. Third Edition. Sydney and New York: Pergamon Press.

[9] Roesmanto, T. (2007). Utilization of the Local Potential Architecture Indonesia. Publisher Agency Diponegoro University, Semarang.

[10] Saimul, S., Tambunan, M., Oktaviani, R., \& Firdaus, M. (2017). Influence Analysis Export Manufacturing Industry In Indonesia Macroeconomic Performance. Journal of Organization and Management, 7 (2), 75 85.

[11] Siregar, H., \& Wahyuniarti, D. (2007). The impact of economic growth on the decline in the number of poor people. IPB and the Brighten Institute.

[12] Sugiyono, FX (2017). Balance of payments: Concepts, methodology and implementation (Vol. 4). Kebanksentralan Center for Education Studies (PPSK) Bank Indonesia.

[13] Tambunan, Tulus., \& Wijanarko. (2000). International Trade and Balance of Payments: theory and empirical findings. LP3ES.

[14] Tambunan, Tulus. (2001). Indonesian Economy: Theory and Empirical Findings, Jakarta: Ghalia Indonesia.

[15] Tan, KG, Merdikawati, N., Amri, M., \& Tan, KY (2017). 2015 Regional Competitiveness Ranking and Analysis for Indonesia: An Annual Update. In 2015 Agricultural Productivity, Decentralization, and Competitiveness Analysis for Provinces and Regions of Indonesia (pp. 45-66).

[16] Widyasanti, AA (2010). Regional Free Trade and Export Competitiveness: The Case of Indonesia. Bulletin of Monetary Economics and Banking (Bulletin of Monetary Economics and Banking), 13 (1), 5-22.

Appendix 1:

Appendix 1:
\begin{tabular}{|l|r|r|r|}
\hline & \multicolumn{3}{|c|}{ Descriptive Statistics } \\
\hline $\mathrm{y}$ & Mean & Std. Deviation & N \\
\hline $\mathrm{x} 1$ & 102782142,1 & 9418241,268 & 15 \\
\hline $\mathrm{x} 2$ & 100530,4 & 42870,6451 & 15 \\
\hline $\mathrm{x} 3$ & 80642,52 & 47972,8426 & 15 \\
\hline $\mathrm{x} 4$ & 23496,7 & 9099,13171 & 15 \\
\hline $\mathrm{x} 5$ & 24216,36 & 13820,70651 & 15 \\
\hline
\end{tabular}

Appendix 2:

Pearson Correlation

\begin{tabular}{|c|c|c|c|c|c|c|c|}
\hline \multicolumn{8}{|c|}{ Correlations } \\
\hline & & $\mathrm{Y}$ & $\mathrm{x} 1$ & $\mathrm{x} 2$ & $\mathrm{x} 3$ & $\mathrm{x} 4$ & $\times 5$ \\
\hline \multirow{6}{*}{$\begin{array}{c}\text { Pearson } \\
\text { Correlation }\end{array}$} & $\mathrm{y}$ & 1 & 0,939 & 0,947 & 0,705 & 0,848 & 0,605 \\
\hline & $\mathrm{x} 1$ & 0,939 & 1 & 0,982 & 0,901 & 0,953 & 0,749 \\
\hline & $\mathrm{x} 2$ & 0,947 & 0,982 & 1 & 0,873 & 0,947 & 0,668 \\
\hline & $\mathrm{x} 3$ & 0,705 & 0,901 & 0,873 & 1 & 0,934 & 0,789 \\
\hline & $\mathrm{x} 4$ & 0,848 & 0,953 & 0,947 & 0,934 & 1 & 0,737 \\
\hline & $x 5$ & 0,605 & 0,749 & 0,668 & 0,789 & 0,737 & 1 \\
\hline \multirow{6}{*}{$\begin{array}{l}\text { Sig. (1- } \\
\text { tailed) }\end{array}$} & $\mathrm{y}$ &. & 0 & 0 & 0,002 & 0 & 0,008 \\
\hline & $\mathrm{x} 1$ & 0 & . & 0 & 0 & 0 & 0,001 \\
\hline & $\mathrm{x} 2$ & 0 & 0 & . & 0 & 0 & 0,003 \\
\hline & $\mathrm{x} 3$ & 0,002 & 0 & 0 & . & 0 & 0 \\
\hline & $\mathrm{x} 4$ & 0 & 0 & 0 & 0 & . & 0,001 \\
\hline & $\times 5$ & 0,008 & 0,001 & 0,003 & 0 & 0,001 &. \\
\hline $\mathrm{N}$ & $\mathrm{y}$ & 15 & 15 & 15 & 15 & 15 & 15 \\
\hline
\end{tabular}


Growth of oil/gas sectors and non oil/gas trade: The impact on labor-force participation rates...

\begin{tabular}{|l|l|l|l|l|l|l|l|}
\hline & $\mathrm{x} 1$ & 15 & 15 & 15 & 15 & 15 & 15 \\
\cline { 2 - 8 } & $\mathrm{x} 2$ & 15 & 15 & 15 & 15 & 15 & 15 \\
\cline { 2 - 8 } & $\mathrm{x} 3$ & 15 & 15 & 15 & 15 & 15 & 15 \\
\cline { 2 - 8 } & $\mathrm{x} 4$ & 15 & 15 & 15 & 15 & 15 & 15 \\
\cline { 2 - 8 } & $\mathrm{x} 5$ & 15 & 15 & 15 & 15 & 15 & 15 \\
\hline
\end{tabular}

Appendix 3:

Model Summary $^{b}$

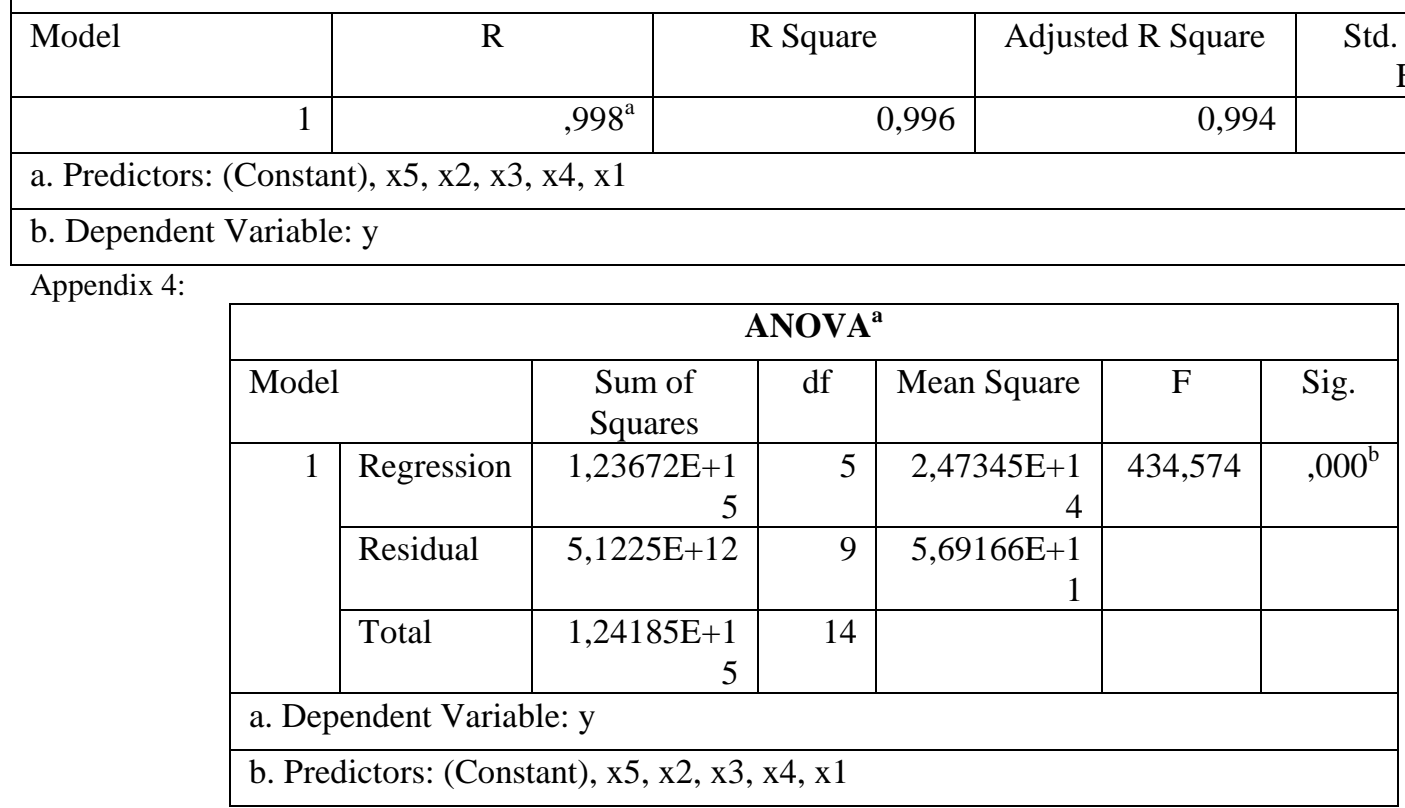

Appendix 5:

\begin{tabular}{|c|c|c|c|c|c|c|c|c|c|}
\hline & & & & Coefficients $^{\mathrm{a}}$ & & & & & \\
\hline Mode & & Unstandardize & Coefficients & Standardized & $\mathrm{t}$ & Sig. & & orrelatior & \\
\hline & & B & Std. Error & Beta & & & $\begin{array}{l}\text { Zero- } \\
\text { order }\end{array}$ & Partial & Part \\
\hline 1 & (Constant) & $\begin{array}{r}86823908,8 \\
9 \\
\end{array}$ & $\begin{array}{r}1308654,49 \\
7\end{array}$ & & 66,346 & 0 & & & \\
\hline & $\mathrm{x} 1$ & 229,669 & 34,052 & 1,045 & 6,745 & 0 & 0,939 & 0,914 & 0,144 \\
\hline & $\mathrm{x} 2$ & 101,414 & 28,246 & 0,517 & 3,59 & 0,006 & 0,947 & 0,767 & 0,077 \\
\hline & $\mathrm{x} 3$ & $-796,075$ & 68,492 & $-0,769$ & $-11,623$ & 0 & 0,705 & $-0,968$ & $-0,249$ \\
\hline & $\mathrm{x} 4$ & 28,331 & 62,352 & 0,042 & 0,454 & 0,66 & 0,848 & 0,15 & 0,01 \\
\hline & $\mathrm{x} 5$ & 510724,21 & 400910,293 & 0,053 & 1,274 & 0,235 & 0,605 & 0,391 & 0,027 \\
\hline
\end{tabular}


Growth of oil/gas sectors and non oil/gas trade: The impact on labor-force participation rates...

Appendix 6:

\begin{tabular}{|l|r|r|r|r|r|}
\hline \multicolumn{7}{|c|}{ Residuals Statistics $^{\text {a }}$} \\
\hline & Minimum & Maximum & Mean & $\begin{array}{c}\text { Std. } \\
\text { Deviation }\end{array}$ & N \\
\hline $\begin{array}{l}\text { Predicte } \\
\text { d Value }\end{array}$ & 91325112 & 11788945 & 102782142, & 9398796,51 & 1 \\
\hline Residual & - & 1126897,5 & 0 & 604890,630 & 5 \\
& 1097072,37 & & & 4 & 5 \\
& $-1,219$ & 1,607 & 0 & 1 & 1 \\
Std. & & & & & 5 \\
Predicte & $-1,454$ & 1,494 & 0 & 0,802 & 1 \\
\hline $\begin{array}{l}\text { Std. Value } \\
\text { Residual }\end{array}$ & & & & & 5 \\
\hline a. Dependent Variable: $y$ & & & & \\
\hline
\end{tabular}

Andi Sessu " Growth of Oil/Gas Sectors And Non Oil/Gas Trade: The Impact on Labor-Force Participation Rates In Indonesia.” The International Journal of Engineering and Science (IJES), vol. 6, no. 12, 2017, pp. 01-10. 